\title{
DOES FINANCIAL DEVELOPMENT HAMPER ECONOMIC GROWTH: EMPIRICAL EVIDENCE FROM BANGLADESH
}

\author{
Qazi Muhammad Adnan Hye ${ }^{1}$, Faridul Islam² \\ ${ }^{1}$ Economics Department, Faculty of Economics and Administration, \\ University of Malaya, Malaysia \\ ${ }^{2}$ Department of Economics, Morgan State University, 311H Holmes Hall, 1700 E Cold Spring \\ Lane, Baltimore, MD 21251 \\ E-mails: ${ }^{1}$ adnan.economist@yahoo.com (correspondingauthor); ${ }^{2}$ Faridul.Islam@morgan.edu \\ Received 17 July 2011; accepted 03 January 2012
}

\begin{abstract}
The objective of this study is twofold. (a) Construct the first ever financial development index (FDI) for Bangladesh using the principal component method (PCM). (b) Use the FDI to explore the existence of a long run relationship between FDI and economic growth. The Augmented Dickey Fuller and the Ng-Perron unit root tests have been applied to examine the stationarity properties of the series. To explore a long run relation, the Autoregressive Distributed Lag (ARDL) approach to cointegration; and to assess the stability of the parameters, the rolling window regression approach have been used. The results show that the impact of real interest rate (RIR) and FDI on economic growth is negative. Estimates from rolling window method show that FDI and RIR are negatively related to economic growth for the years 1987-1988, 1992-1999, 2002-2006, 2008 and 2009; and 1986-1998, 2006 and 2007, respectively. The results may help policymakers formulate effective financial sector policies as a tool to promote economic growth in Bangladesh.
\end{abstract}

Keywords: Financial Development Index, ARDL, Principal Component Method.

Reference to this paper should be made as follows: Hye, Q. M. A.; Islam, F. 2013. Does financial development hamper economic growth: empirical evidence from Bangladesh, Journal of Business Economics and Management 14(3): 558-582.

JEL Classification: F43, O47.

\section{Introduction}

Financial repression refers to a notion where government regulations, laws, and other non-market restrictions prevent the financial intermediaries of an economy from functioning at their optimal capacity. Financial repression can be caused by interest rate ceilings, requirements to maintain high liquidity or reserve ratio, capital controls, restrictions on entry into the financial sector, credit restrictions, and ceilings on allocation, government ownership and control of banks.

McKinnon (1973) and Shaw (1973) first introduced the notion of financial repression. In theory, an economy with an efficient financial market should grow faster due to efficient 
allocation of capital. Government regulations create inefficiency in the capital market which lowers the rate of return, compared to competitive market. When financial intermediaries cannot function optimally, saving and investment is discouraged and overall economic growth is impeded. As a corollary, alleviation of financial repression can have positive impact on economic growth. This line of reasoning enjoys broad theoretical and empirical support (e.g. Romer 1986; King, Levine 1993; Levine, Zervos 1998; Wachtel 2003; Seetanah 2007; Ang 2008).

In the extant literature on the relationship between financial development and economic growth, two strands in research can be identified. First, researchers use a single measure of financial development and test its relationship with economic growth for a number of countries using cross section or panel data technique. Levine, Zervos (1998) explored the link between banking development and economic growth of the developed and less developed countries ${ }^{1}$. Using the GMM method, he found a positive relationship between the two series. Luintel and Khan (1999) examined the causal relationship between financial development and economic growth for ten less developed countries ${ }^{2}$ and found that financial depth positively affects real income and real interest rate. Their findings showed bi-directional causality between financial development and economic growth for the countries studied. Rousseau and Wachtel (2000) used the ratio of market capitalization to GDP and the value of trades to GDP, per capita trade value, per capita market capitalization, and real per capita M3 as indicators of banking and stock market development. They found that banking and stock market development have strong impact on economic growth. Yay and Oktayer (2009) used the data of bank credit ${ }^{3}$ and stock market development as indicators of financial development for 21 developing $^{4}$ and 16 developed economies ${ }^{5}$. They found that both stock market development and bank credit are positively related to economic growth in the developing countries; whereas only stock market affects economic growth in the developed countries. Second, researchers use time series techniques to examine the above noted relationship for a particular country (Murinde and Eng (1994) for Singapore; Lyons and Murinde (1994) for Ghana; Odedokun (1989) for Nigeria; Agung and Ford (1998) for Indonesia; and Wood (1993) for Barbados.) This paper contributes to this second strand of the literature.

\footnotetext{
${ }^{1}$ Argentina, Australia, Austria, Bangladesh, Belgium, Brazil, Canada, Chile, Colombia, Cote d'Ivoire, Costa Rica, Germany, Denmark, Egypt, Spain, Finland, France, United Kingdom, Greece, Hong Kong, Indonesia, India, Israel, Italy, Jamaica, Jordan, Japan, Korea, Luxembourg, Mexico, Malaysia, Morocco, Nigeria, The Netherlands, Norway, New Zealand, Pakistan, Peru, Philippines, Portugal, Singapore, Sweden, Sri Lanka, Thailand, Turkey, Taiwan, United States, Venezuela, and Zimbabwe.

${ }^{2}$ Colombia, Costa Rica, Greece, India, Korea, Malaysia, Philippines, Sri Lanka, South Africa, Thailand.

3 The ratio of bank claims on the private sector deposit money banks to GDP.

${ }^{4}$ Brazil, Chile, Colombia, Egypt, Greece, India, Indonesia, Israel, Jordan, Korea Republic, Malaysia, Mexico, Pakistan, Peru, Philippines, Portugal, South Africa, Thailand, Turkey, Venezuela, Zimbabwe.

5 Australia, Austria, Belgium, Canada, Denmark, Finland, France, Germany, Great Britain, Italy, Japan, Netherlands, New Zealand, Norway, Sweden, USA.
} 
The hypothesis that alleviation of financial repression can promote economic growth has prompted several developing nations to initiate financial liberalization policies beginning in the mid 1980's. The government of Bangladesh responded by launching Financial Sector Reforms policy early in the 1990s as a part of Structural Adjustment Program (SAP). The aim was to help improve the link between finance and economic growth. The reforms include liberalization of deposits and lending rates, indirect monetary management, modernization of the banking sector, development of capital market, loan classification, prudential regulations, strengthening the central bank's supervisory ability, and a legal framework for debt recovery.

The objective of this study is to empirically examine the long and the short run relationship between financial development and economic growth by constructing the first ever financial development index (FDI) for Bangladesh. In the literature different proxies have been used to measure financial development and their link to economic growth ${ }^{6}$. Kelly and Mavrotas (2003) argue that the impact on the real GDP varies by the choice of an indicator of financial development. An index provides a better representation of the development of overall financial sector; and tends to be more reliable compared to a single indicator. The use of an index in this paper will help Bangladesh policymakers identify areas where further reforms in the financial sector are warranted. Despite its significance for economic growth in a globalized world, such a study has not been undertaken for Bangladesh, a nation of 165 million in the South Asian region. The paper contributes by exploring a relation between economic growth and FDI for Bangladesh and fills a much needed gap in knowledge.

The rest of the paper is organized as follows. Section 2 reviews theoretical and empirical literature. Section 3 develops financial development index. Section 4 describes the data and estimation strategy. Sections 5 and 6 report the empirical results, and the conclusion, respectively.

\section{Theoretical and empirical literature review}

Three types of opinions are available in the theoretical literature on financial and economic growth association. First, in his pioneering study, Schumpeter (1911) identified positive effect of financial development on productivity and economic growth. He stated that financial intermediaries play a central role in the enhancement of technological transformation and economic development by offering essential services such as, channeling the savings towards productive investment. More recently McKinnon (1973) and Shaw (1973) presented the concept of financial liberalization enhancing growth. Further, the growth enhancing argument is supported by new growth theories of Romer (1986), Barro (1991), Japelli and Pagano (1994).

The second view states that finance is relatively less important for economic growth. Robinson (1952) pointed out that financial development does not cause economic

\footnotetext{
${ }^{6}$ See Rousseau and Watchel 1998; Xu 2000; Fase, Abma 2003; Rioja, Valev 2004; Rahman 2004, 2007; Hassan and Islam 2005; Shahbaz 2009.
} 
growth. Instead economic growth leads to financial development. Lucas (1988) stated that physical capital, human capital and technological change are the only factors that influence economic growth. According to this view the growth in real sector increases the demand for various financial services which is met by the financial sector. This view proposes that financial development simply pursues economic growth.

The third opinion argues that financial development exerts negative impact on economic growth. Van Wijnbergen (1982) and Buffie (1984) stated that financial developments can have none or a negative impact on economic growth. As the formal financial system develops, funds move from the controlled market to the formal market. Due to the restrain (reserve requirement) in formal markets all the funds cannot advance. This reduces domestic credit supply, giving rise to a credit crunch which can retard economic growth by lowering investment and slowing production. Singh (1997) suggested that financial development impedes economic growth when it induces instability and discourages risk-averse investors from investing. In addition, Mauro (1995) pointed out that the introduction of specific financial tools that permit individuals to hedge against risks may reduce the precautionary saving and thus impede economic growth.

The empirical literature on the finance-growth nexus is very broad. A positive correlation between financial development and economic growth is documented by McKinnon (1973) and Shaw (1973), Gupta (1984), Jung (1986), Choe and Moosa (1999), Levine and Beck (2000); Sachsida (2001); Mattoo et al. (2006), Ang and Mckibbin (2007) ${ }^{7}$. La Porta et al. (2002) find that government ownership of banks is pervasive and more prevalent in low income countries. Countries with poor financial systems, inefficient governments, and insecure property rights tend to have lower growth in per capita income and productivity. This supports the "political" theories of the effects of government ownership of firms. Khan and Qayyum (2007) examine the relationship between financial development and economic growth for high income countries. They examine impact of indirect and direct finance, separately and jointly, using the Nair-Reichert and Weinhold (2001) approach to causality to heterogeneous panel data; and report two sets of results. First, the results on the relationship between financial development and economic growth are mixed ${ }^{8}$. Second, their results contrast those found by Beck and Levine (2004). Specifically, when the heterogeneous panel causality analysis is applied to a refined model, they fail to establish direction of causality. While the results lend support for Robinson (1952, finance follows enterprise) in the context of stock market activity, they argue that the importance of financial matters may have been overstressed. Güryay et al. (2007) examine the relationship between financial development and economic growth for Northern Cyprus. They found financial development does not Granger cause economic growth, but the reverse causality holds. However, the relation is positive but negligible.

\footnotetext{
${ }^{7}$ In contrast financial development does not always produce desirable outcomes because the relative strength of financial sector is different in the countries level.

8 The results obtained from contemporaneous non-dynamic fixed effects panel estimation. Negative but statistically significant estimates of the coefficient of the interaction variable between inflation and financial development indicate that the latter may even hurt economic growth in a situation of rising inflation.
} 
There are several channels through which financial development promotes economic growth. Bencivenga and Smith (1991) attribute this to the role financial intermediaries. Using endogenous growth model with multiple assets they consider the effects of financial intermediation which shifts the composition of savings toward capital, suggesting that intermediation is growth promoting. Intermediaries reduce socially unnecessary capital liquidation and support growth. De Gregorio and Guidotti (1995) suggest that financial intermediation positively affects economic growth through efficient investment rather than volume. Levine (1997) note that capital accumulation and technological channels affect financial development and thus economic growth. Levine and Zervos (1998) suggest that stock market liquidity and banking development positively influence economic growth. Xu (2000) argues that financial development affects economic growth via investment channels. Carlin and Mayer (2003) found a robust relationship between financial system and industrial growth.

An emerging literature points out that financial liberalization creates financial fragility instead of economic stability. Gertler and Rose (1994) examined a number of developing countries and found that financial liberalization slows economic growth and increases the rate of inflation ${ }^{9}$. Arphasil (2001) argues that the reason behind the East Asian Flu (1997-98) was the credit boom, triggered by interest rate and capital account liberalization. Short term capital flow and the resulting boom lead to instability and financial crises. Wyplosz (2002) suggest that financial liberalization should be gradual; beginning with domestic and then extended to external market. He cautions that proper integration of domestic financial markets with global market may take decades. The integration of the postwar European market which was not completed until late in the 1980s is a case in point (see Wyplosz 2001).

Financial repression serves the interest of those in power and can unleash a liberalization process that is in line with the "Washington consensus". Such policy was applied in a number of transitional economies. However, liberalization done in haste can cause deep currency crises, e.g. the EMS crisis of 1992-93 and the Asian crisis of 1997-98. Khan and Islam (2008) disagree with this point of view. They blame the Chinese devaluation of 1994 for the crisis. Singh et al. (2003) also disagree with the perception that the fundamental causes of the Asian crisis were imperfect systems of corporate governance and poor competitive environment in the affected countries. Many argue that the crisis was precipitated by liberalization of capital market; which might be explained by the Turkish currency crises (Mete 2007).

In the context of finance and growth nexus for Bangladesh, Rahman (2004) found that financial development positively impacts per capita income and investment-GDP ratio. He used domestic credit to private sector as a percentage of GDP; total deposit as a percentage of GDP and broad money as a percentage of GDP as indicators of financial

\footnotetext{
${ }^{9}$ Because financial liberalization associated a general rise in interest rates that was cause a rise in the cost of capital. According to this observation, financial liberalization cause to increase in interest rates and manufacturing costs, causing prices to increase.
} 
development. Hassan and Islam (2005) examined the causal relationship between finance and growth. They reject both finance led growth and growth led finance hypothesis for Bangladesh. Rahman (2007) investigated the long-run impact of financial development on capital formation and per capita income ${ }^{10}$. The response matrix lends support for the long-run relation between various indicators of financial development and investment on per capita income. The findings do not support the notion that lending rates have any impact on per capita income, financial development, or investment which they blame on small degree of monetization. Based on the Impulse Response Functions for the short-run dynamics among the series, both financial development and investment are found to exert short-run impact on per capita income during the immediate year following the shocks. The Variance Decomposition results suggest that lending rate; indicators of financial development; and investment contain very useful information to predict the future path of per capita income.

\section{Construction of financial development index}

The financial sector reforms in Bangladesh are divided in two phases. The initial reforms were started in 1990s and the second one was launched in late 2001. In 1990s the reforms were started on the suggestion of National Commission on Money, Banking and Credit, and the World Bank. The main aims of financial sector reforms were as follows: liberalization of interest rates; indirect monetary management; implementation of capital adequacy requirement for commercial banks; introduction of new policies for loan classification; transformation of banking sector; updating accounting system; amendment of the legal structure of financial sector; development of capital market; intensification of central bank's supervision; improvement of overall management of the banking sectors with special emphasis on credit management; and computerization of the operation of the central bank and the government owned commercial banks.

In the second phase of financial sector reforms, the repurchase agreement (repo) was introduced in July 2002 and reverse repo was launched in April 2003. The Bangladesh Taka was floated in May 2003 in the foreign exchange market. After that a number of legal, regulatory, and operational reforms of non-performing loan were started. In order to strengthen the capital base, the minimum paid up capital of a bank was raised from Taka 200 million (\$3.4 million) to Taka 1000 million (\$17 million). The literature indicates that researcher constructed financial indicator to investigate the impact of financial sector reforms on growth. They applied two different methods to construct financial index to analyze the impact of financial reforms on economic growth. First, Bandiera et al. (2000) constructed financial indicator by using different features of financial institutional reforms and regulations. In particular, they used eight policy components of financial indicators: interest rate deregulation, pro-competition measures, reserve requirements, directed credit, bank ownership, prudential regulations, stock markets reform and international financial liberalization. This approach was applied by Laeven (2003), Nair (2004), Shrestha et al. (2005), Ahmed (2007) and Hye et al. (2011).

\footnotetext{
10 The author uses the Blanchard and Quah's (1989) technique of structural vector autoregressions.
} 
Secondly, in an environment where financial sector is based on the banking system rather than on the market, it is a complex exercise to quantify government deregulation policies and institution-building (Kelly, Mavrotas 2003; Ang, Mckibbin 2007). Ang and Mckibbin (2007) constructed FDI for Malaysia by using the three indicators. For the first two indicators, they used liquid liabilities and domestic credit to private sectors as a ratio of nominal GDP. For the third one, the ratio of commercial bank assets to commercial bank assets plus central bank assets was used. Khan and Qayyum (2007) chose four indicators of financial development to construct FDI for Pakistan: total bank deposit liabilities; clearing house amount; private credit and the stock market capitalization, each as ratio of GDP. Kar et al. (2008) used three proxies of financial development $\left(\mathrm{M} 1 / \mathrm{Y} ; \mathrm{M} 1 / \mathrm{M} 2\right.$ and M2/Y) ${ }^{11}$ for financial liberalization index for Turkey. Hye (2011) constructed financial development index for India by using four proxy indicators of financial development - market capitalization of listed companies, liquid liabilities and domestic credit to private sector as a percentage of GDP, and M2/M1.

The present study follows the second approach just described above to construct FDI for Bangladesh. We do so because financial institutions in Bangladesh are dominated by the banking sector which accounts for 95 percent in the financial system (Sufian, Habibullah 2009; Bahar 2009). The formal financial sector in Bangladesh includes the Bangladesh Bank (the central bank), 48 commercial banks and 28 non-bank financial institutions. The index focuses more on the financial development in the context of the banking sector. The five ratios used here are: liquid liabilities (M3) as \% of GDP; domestic credit provided by banking sector as \% of GDP; domestic credit to private sector as \% of GDP; money plus quasi money (M2) as ratio of money (M1); and market capitalization of listed companies as $\%$ of GDP ${ }^{12}$. The weight of each series is computed by using the principal component method (PCM).

The principal component method (PCM) was first coined by Pearson (1901) and then developed by Hotelling (1933). The PCM uses a multivariate technique to examine the relationships among several quantitative variables. The method has been widely applied to many areas including computation of environmental index (Kang et al. 2002). More recently, Agénor (2003) computed a simple globalization index using PCM and applied it to trade and financial openness. In terms of methodology, for any given data set with $p$ variables, at most $p$ principal components (PC) can be computed, each being a linear combination of the original variables, where the coefficients equal the eigenvectors of the correlation of covariance matrix. The PC is then sorted by descending order of the eigen values, which are equal to the variance of the components. Note that the eigenvectors are taken of unit length. The first component has the largest variance of any unit length linear combination of the determinant variables, and likewise for the last component. The PCM can be expressed as:

${ }^{11}$ M1: Narrow Money; M2: Broad Money and Y: Gross domestic product.

12 Economists often use these ratios as an indicator of financial development (see Rousseau and Watchel 1998; Xu 2000; Fase \& Abma 2003; Rioja and Valev 2004; Rahman 2004, 2007; Hassan and Islam 2005; Shahbaz 2009). 


$$
Z_{j}=a_{j, 1} F_{1}+a_{j, 2} F_{2}+\cdots+a_{j, n} F_{n}+d_{j} U_{j},
$$

where, each of the 1 to $n$ observed variables $Z_{i}$ is described linearly in terms of $n$ new uncorrelated components $F_{1}, F_{2} \cdot F_{n}$ each of which in turn is a linear combination of the $n$ original variables. The coefficient $a_{i j}$ is the regression weight on the ith factor and $U_{i}$ denotes a unique factor, influenced by idiosyncratic determinants. The critical issue here is to obtain the best linear combination. Table 1 reports the results from PCM.

Table 1. Financial development index analysis

\begin{tabular}{|c|c|c|c|c|c|}
\hline \multicolumn{6}{|c|}{ Eigenvalues: $($ Sum $=5$, Average $=1)$} \\
\hline Number & Value & Difference & Proportion & $\begin{array}{l}\text { Cumulative } \\
\text { Value }\end{array}$ & $\begin{array}{l}\text { Cumulative } \\
\text { Proportion }\end{array}$ \\
\hline 1 & 4.516 & 4.155 & 0.903 & 4.516 & 0.903 \\
\hline 2 & 0.360 & 0.281 & 0.072 & 4.8773 & 0.975 \\
\hline 3 & 0.080 & 0.053 & 0.016 & 4.957 & 0.991 \\
\hline 4 & 0.026 & 0.011 & 0.005 & 4.984 & 0.996 \\
\hline 5 & 0.015 & - & 0.003 & 5.000 & 1.000 \\
\hline \multicolumn{6}{|c|}{ Eigenvectors (loadings): } \\
\hline Variable & PC 1 & PC 2 & PC 3 & PC 4 & PC 5 \\
\hline $\mathrm{M}$ & 0.464 & -0.123 & -0.317 & 0.048 & -0.815 \\
\hline $\mathrm{DCP}$ & 0.459 & -0.191 & -0.578 & 0.359 & 0.537 \\
\hline DC & 0.465 & -0.087 & 0.057 & -0.854 & 0.204 \\
\hline $\mathrm{M} 2 / \mathrm{M} 1$ & 0.446 & -0.376 & 0.734 & 0.341 & 0.045 \\
\hline $\mathrm{MC}$ & 0.396 & 0.893 & 0.147 & 0.143 & 0.042 \\
\hline \multicolumn{6}{|c|}{ Ordinary correlations: ${ }^{13}$} \\
\hline & $\mathrm{M}$ & $\mathrm{DCP}$ & DC & $\mathrm{M} 2 / \mathrm{M} 1$ & $\mathrm{MC}$ \\
\hline M & 1.000 & & & & \\
\hline $\mathrm{DCP}$ & 0.981 & 1.000 & & & \\
\hline $\mathrm{DC}$ & 0.975 & 0.961 & 1.000 & & \\
\hline $\mathrm{M} 2 / \mathrm{M} 1$ & 0.936 & 0.922 & 0.946 & 1.000 & \\
\hline $\mathrm{MC}$ & 0.788 & 0.754 & 0.801 & 0.688 & 1.000 \\
\hline
\end{tabular}

Notes: $\mathrm{M}=$ Liquid liabilities (M3) as \% of GDP, DCP = Domestic credit provided by banks $(\%$ of GDP); DC = Domestic credit to private sector (\% of GDP); M2/M1 = Money plus quasi money divided by money; and Market capitalization of listed companies ( $\%$ of GDP).

The first PC explains about $90.3 \%$, the second PC explains 7.2\%, the third and fourth PC another $1.6 \%$ and $0.05 \%$ respectively and the last principal component accounts for $0.03 \%$ of the standardized variance. Thus we select the first PC to calculate financial

13 The correlations matrix shows the proxies of financial development highly correlated with each other. 
development index. The first PC is a linear combination of the three standard measures of financial development with weights given by the first eigen vector. After rescaling, the individual contributions of each series M, DCP, DC, M2/M1 and MC to the standardized variance of the first principal component are found to be $46.4 \%, 45.9 \%, 46.5 \%$, $44.6 \%$ and $39.6 \%$ respectively. This study uses these weights to construct a summary measure of FDI, as shown in Figure 1. This index describes the structural changes of financial sector development in Bangladesh.

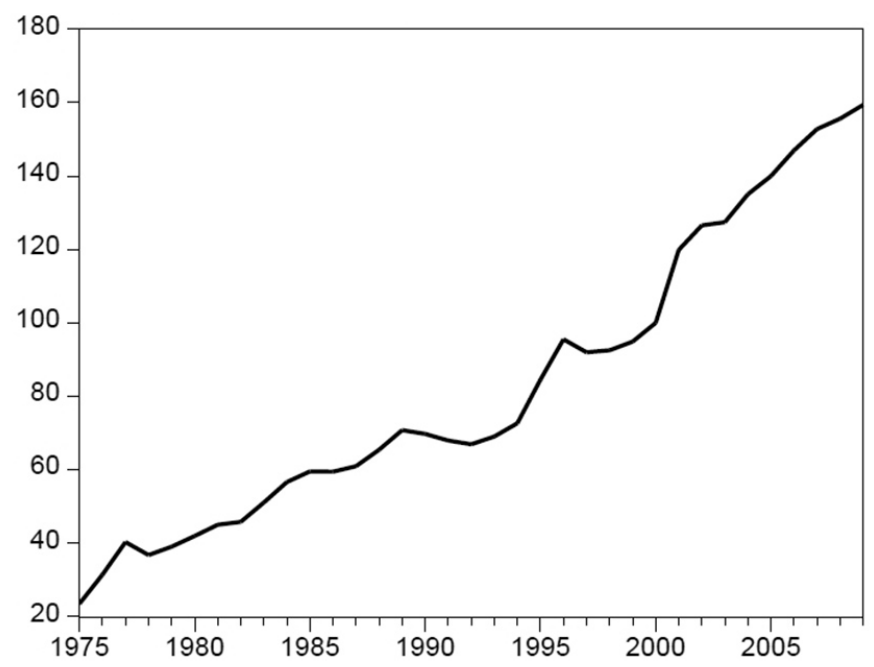

Fig. 1. Financial development index for Bangladesh

\section{Data and estimation strategy}

\subsection{Data}

The paper uses annual time series data from 1975-2009. All variables, gross domestic product (GDP), total labor forces (L), gross fixed capital formation (K), and real interest rate (RIR) has been taken from World Development Indicators CD ROM of the World Bank. We construct and implement the first ever financial development index (FDI) for Bangladesh. This step helps us finesse the problems associated with the use of a single indicator. The GDP and K are measured in domestic currency at constant 2000 prices, and $\mathrm{L}$ is measured in numbers. The following relation is postulated.

$$
Y=f(L, K, R I R, F D I)
$$

The specification of the linear formulation is provided in equation (3).

$$
\operatorname{Ln}(Y)_{t}=\beta_{0}+\beta_{1} \operatorname{Ln}(L)_{t}+\beta_{2} \operatorname{Ln}(K)_{t}+\beta_{3} \operatorname{Ln}(R I R)_{t}+\beta_{4} \operatorname{Ln}(F D I)_{t}+\mu_{1, t},
$$

where $\operatorname{Ln}(Y)_{t}, \operatorname{Ln}(L)_{t}, \operatorname{Ln}(K)_{t}, \operatorname{Ln}(R I R)_{t}$ and $\operatorname{Ln}(F D I)_{t}$ are natural logarithm of the variables described earlier, and $\mu_{t}$ is the random error term. 


\subsection{Methodology}

The paper employs the Augmented Dickey Fuller (ADF) and relatively new Ng-Perron unit root tests to determine the order of integration of each series. The ADF test is based on equation (4).

$$
\Delta Y_{t}=\alpha_{0} T+\alpha_{2} Y_{t-1}+\sum_{j=1}^{k} d_{j} \Delta Y_{t-j}+\epsilon_{t},
$$

where, $\varepsilon_{t}$ is pure white noise process, $Y_{t}$ is the series of interest for unit root. $T$ is a linear time trend, $\Delta$ is the first difference operator, $\alpha_{0}$ is a constant, and $\mathrm{k}$ is the optimum number of lags needed to induce white noise property. The null hypothesis for testing non-stationarity is H0: $\alpha_{2}=0$, i.e. the time series are non-stationary ${ }^{14}$. The Ng-Perron $(2001)^{15}$ unit root test is based on the following four statistics: Phillips-Perron $Z_{a}$ and $Z_{t}$, Bhargava $\mathrm{R}_{1}$ and ERS optimal statistic. The tests are based on GLS de-trended data, $\ddot{A} y_{t}$.

Define,

$$
k=\sum_{t-2}^{T}\left(y_{t-1}^{d}\right)^{2} / T^{2},
$$

The four statistics are listed below.

$$
\begin{gathered}
M Z_{a}^{d}=\left(\left(T^{1} y_{T}^{d}\right)^{2}-f_{0}\right) / 2 k, \\
M Z_{t}^{d}=M Z_{a} \times M S^{\prime} \\
M S B^{d}=\left(\frac{k}{f_{0}}\right)^{12^{\prime}}
\end{gathered}
$$

and,

$$
M P_{T}^{d}=\left(\bar{c}^{2} k-\bar{c} T^{1}\right)\left(y^{d} T\right)^{2} / f_{0} \text { if } x_{t}=\{1, t\}^{\prime}
$$

where,

$$
\bar{c}=-7 \text { if } x_{1}=\{1\}
$$

and,

$$
\bar{c}=-13.5 \text { if } x_{t}=\{1, t\} \text {. }
$$

\footnotetext{
14 That is $z_{t}$ is a random walk with unit root. If the t-statistic of $\alpha_{2}$ is less than the critical value at the chosen level of significance, the null hypothesis of non-stationary cannot be rejected.

15 This test has good explanatory power in small samples.
} 


\subsection{ARDL approach to cointegration}

The paper implements the Autoregressive Distributed Lag (ARDL) approach to cointegration a la Pesaran et al. (2001). The approach is preferable to other conventional techniques, e.g. Engle and Granger (1987), Johansen (1991), and Gregory and Hansen's (1996) for several reasons. ARDL applies irrespective of whether the underlying regressors are purely I(0), I(1), or mutually integrated. The statistic underlying the procedure is the familiar F-statistic and Wald-statistic in a generalized Dickey-Fuller type regression, which is used to test the significance of the lagged levels of the variables under consideration within a conditional Unrestricted Equilibrium Error Correction Model (Pesaran et al. 2001). The ARDL approach involves estimating the conditional error correction version for the variables. The augmented ARDL $\left(\rho, q_{1}, q_{2}, \ldots \ldots q_{k}\right)$ is given by the following equation (Pesaran, Pesaran 1997; Pesaran et al. 2001):

$$
\begin{gathered}
a(L, \rho) y_{t}=\alpha_{0}+\sum_{i-1}^{k} \beta_{i}\left(L, q_{i}\right) x_{i, t}+\beth^{\prime} w_{t}+\varepsilon_{t}, \\
\forall t=1, \ldots \ldots \ldots, n,
\end{gathered}
$$

where

$$
\begin{aligned}
& \alpha(L, \rho)=1-\alpha_{1} L-\alpha_{2} L^{2}-\ldots \ldots . .-\alpha_{\rho} L^{\rho}, \\
& \beta_{i}\left(L, q_{i}\right)=\beta_{i^{\circ}}+\beta_{i, 1} L+\beta_{i, 2} L^{2}+\ldots \ldots .+\beta_{i . q_{i}} L^{q_{i} \forall_{i}}=1,2 \ldots, k,
\end{aligned}
$$

$y_{t}$ is the dependent variable, $\alpha$ is a constant term, $L$ is a backshift operator such that $L y_{t}=y_{t-1}, w_{t}$ is $s \times 1$ vector of deterministic variables such as intercept term, time trends, or exogenous variables with fixed lags. The $x_{i t}$ in equation-5 is the $i$ th independent variable where $i=1,2, \ldots, k$. The long run equation with respect to the constant term can be written as follows:

$$
\begin{gathered}
y=\alpha_{0}+\sum_{i=1}^{k} \beta_{i} x_{i}+\delta^{\prime} w_{t}+v_{t}, \\
\Omega=\alpha_{0}^{1} / \Omega(1, \rho) .
\end{gathered}
$$

The long run coefficients for response of $y_{t}$ to a unit change in $x_{i t}$ are investigated by:

$$
\begin{gathered}
\varnothing_{i}=\beta_{i}\left(1, q_{i}\right) \alpha(1, \rho)=\hat{\beta}_{i, 0}+\hat{\beta}_{i, 1}+\ldots . .+\hat{\beta}_{i, \hat{q}_{i}} 1-\hat{\alpha}_{1}-\hat{\alpha}_{2}-\ldots . .-\hat{\alpha}_{\hat{\rho}}, \\
\forall i=1,2, \ldots, k,
\end{gathered}
$$

where $\hat{\rho}$ and $\hat{q}_{i}, \mathrm{i}=1,2, \ldots, k$ are the estimated values of $\hat{\rho}$ and $\hat{q}_{i}, \mathrm{i}=1,2, \ldots, k$. The long run coefficients are estimated by:

$$
\pi=\frac{\hat{\gamma}\left(\widehat{p}, \hat{q}_{1}, \hat{q}_{2, \ldots} \hat{q}_{k}\right)}{1-\hat{\alpha}_{1}-\hat{\alpha}_{2}-\ldots-\hat{\alpha}_{p}},
$$


where $\hat{\gamma}\left(\hat{\rho}, \hat{q}_{1}, \hat{q}_{2}, \ldots . \hat{q}_{k}\right)$ denotes the OLS estimates of $\lambda$ in equation (5) for the selected ARDL model. The error correction model (ECM) linked to the ARDL $\left(\hat{\rho}, \hat{q}_{1}, \hat{q}_{2}, \ldots \hat{q}_{k}\right)$ can be obtained by rewriting equation (5) in terms of lagged levels and the first difference of $y_{t}, x_{1}, x_{2 t}, x_{k t}$ and $w_{t}$ :

$$
\begin{gathered}
\Delta y_{t}=\Delta \alpha_{0}-\alpha(1, \rho) E C_{t-1}+\sum_{i=1}^{k} \beta_{i t} \Delta x_{i, t}+\gamma^{\prime} w_{t}-\sum_{j=1}^{\rho-1} \alpha_{j} \Delta y_{t-1}- \\
\sum_{i=1}^{k} \sum_{j=1}^{q} \beta_{i, j} \Delta x_{i, t-j}+\epsilon_{t},
\end{gathered}
$$

where, the ECM is defined as follows:

$$
E C M_{t}=y_{t}-\alpha-\sum \beta^{\wedge} x_{i, t}-\gamma^{\prime} w_{t}
$$

$x_{t}$ is a $k$-dimensional forcing variable which are not cointegrated among themselves. The $\varepsilon_{t}$ is a vector of stochastic error terms, with zero mean and constant variancecovariance. The ARDL approach involves two steps for estimating the long-run relationship (Pesaran et al. 2001). The first step is to investigate the existence of a long-run relationship among the variables of interest. The second step is to estimate the long- and the short-run coefficients of the equation. The more general formula of ECM with unrestricted intercept is as follows,

$$
\begin{gathered}
\Delta \operatorname{Ln}\left(Y_{t}\right)=c_{0}+\pi_{Y} \operatorname{Ln}(Y)_{t-1}+\pi_{L} \operatorname{Ln}(L)_{t-1}+\pi_{K} \operatorname{Ln}(K)_{t-1}+\pi_{R I R} \operatorname{Ln}(R I R)_{t-1}+ \\
\pi_{F D I} \operatorname{Ln}(F D I)_{t-1}+\sum_{j=1}^{p-1} \Delta \operatorname{Ln}(Y)_{t-j}+\sum_{j=1}^{p-1} \Delta \operatorname{Ln}(L)_{t-j} \sum_{j=1}^{p-1} \Delta \operatorname{Ln}(K)_{t-j}+ \\
\sum_{j=1}^{p-1} \Delta \operatorname{Ln}(R I R)_{t-j}+\sum_{j=1}^{p-1} \Delta \operatorname{Ln}(F D I)_{t-j}+\mu_{t}
\end{gathered}
$$

The F-statistics and Wald-statistic are used to test the null hypothesis,

$H_{0}=\pi_{Y}=\pi_{L}=\pi_{K}=\pi_{R I R}=\pi_{F D I}=0$ of no cointegration against the alternate:

$H_{1}=\pi_{Y}=\pi_{L}=\pi_{K}=\pi_{R I R}=\pi_{F D I} 0$ of cointegration.

The two sets of asymptotic critical values are provided by Pesaran et al. (2001), Narayan (2005), and Turner (2006). The first set assumes that all variables are integrated at level $\mathrm{I}(0)$, while the second set assumes that all variables are integrated of order one I(1). If the computed statistics exceeds the upper critical bound, then the null hypothesis of no cointegration is rejected, i.e. a long run relationship among the series exists. If the test statistics falls within the lower and upper critical bounds, the result is inconclusive. If the statistics is less than the lower critical bound, the null hypothesis is sustained. If a long run relationship exists, then next step is to estimate the long-run and short coefficients. 
In order to investigate the causal relationship the conditional Granger causality test is used under the vector error correction model (VECM). In this way the short-run deviations of the series from their long run equilibrium path can be investigated by including the error correction term $\left(\mathrm{ECT}_{t-1}\right)$ in the model (Narayan, Smyth 2004). Consequently, conditional vector error correction system for Granger causality under the multivariate model is specified as follows:

$$
\begin{aligned}
& \Delta \operatorname{Ln}\left(Y_{t}\right)=\gamma_{1}+\sum_{i=1}^{\rho} \delta_{11} \Delta \operatorname{Ln}(Y)_{t-i}+\sum_{i=0}^{\rho} \delta_{12} \Delta \operatorname{Ln}(L)_{t-i}+\sum_{i=0}^{\rho} \delta_{13} \Delta \operatorname{Ln}(K)_{t-i}+ \\
& \sum_{i=0}^{\rho} \delta_{14} \Delta L n(R I R)_{t-i}+\sum_{i=0}^{\rho} \delta_{15} \Delta L n(F D I)_{t-i}+\gamma e c t_{t-1}+\mu_{1, t} \text {, } \\
& \Delta \operatorname{Ln}\left(L_{t}\right)=\gamma_{1}+\sum_{i=1}^{\rho} \delta_{21} \Delta \operatorname{Ln}(L)_{t-i}+\sum_{i=0}^{\rho} \delta_{22} \Delta \operatorname{Ln}(Y)_{t-i}+\sum_{i=0}^{\rho} \delta_{23} \Delta \operatorname{Ln}(K)_{t-i}+ \\
& \sum_{i=0}^{\rho} \delta_{24} \Delta \operatorname{Ln}(R I R)_{t-i}+\sum_{i=0}^{\rho} \delta_{25} \Delta L n(F D I)_{t-i}+\gamma e c t_{t-1}+\mu_{2, t} \text {, } \\
& \Delta \operatorname{Ln}\left(K_{t}\right)=\gamma_{1}+\sum_{i=1}^{\rho} \delta_{31} \Delta \operatorname{Ln}(K)_{t-i}+\sum_{i=0}^{\rho} \delta_{32} \Delta \operatorname{Ln}(Y)_{t-i}+\sum_{i=0}^{\rho} \delta_{33} \Delta \operatorname{Ln}(L)_{t-i}+ \\
& \sum_{i=0}^{\rho} \delta_{34} \Delta \operatorname{Ln}(R I R)_{t-i}+\sum_{i=0}^{\rho} \delta_{35} \Delta L n(F D I)_{t-i}+\gamma e c t_{t-1}+\mu_{3, t}, \\
& \Delta \operatorname{Ln}\left(R I R_{t}\right)=\gamma_{1}+\sum_{i=1}^{\rho} \delta_{41} \Delta \operatorname{Ln}(R I R)_{t-i}+\sum_{i=0}^{\rho} \delta_{42} \Delta \operatorname{Ln}(Y)_{t-i}+ \\
& \sum_{i=0}^{\rho} \delta_{43} \Delta \operatorname{Ln}(L)_{t-i}+\sum_{i=0}^{\rho} \delta_{44} \Delta \operatorname{Ln}(K)_{t-i}+\sum_{i=0}^{\rho} \delta_{45} \Delta \operatorname{Ln}(F D I)_{t-i}+\gamma e c t_{t-1 \mid+}+\mu_{4, t}, \\
& \Delta L n\left(F D I_{t}\right)=\gamma_{1}+\sum_{i=1}^{\rho} \delta_{51} \Delta L n(F D I)_{t-i}+\sum_{i=0}^{\rho} \delta_{52} \Delta L n(Y)_{t-i}+\sum_{i=0}^{\rho} \delta_{53} \Delta L n(L)_{t-i}+ \\
& \sum_{i=0}^{\rho} \delta_{54} \Delta \operatorname{Ln}(K)_{t-i}+\sum_{i=0}^{\rho} \delta_{55} \Delta \operatorname{Ln}(R I R)_{t-i}+\gamma e c t_{t-1}+\mu_{5, t},
\end{aligned}
$$

where $\Delta, \rho$ and $\mu$ represent the first difference operator, optimum lag length and error term, respectively. The optimum lag length is selected by using the SBC and AIC. The long run and short run causality is tested as follows: In eq-12 the short run causality from labor force, real capital, real interest rate and financial development index to real GDP are tested respectively based on $H_{0}: \delta_{12}=0, H_{0}: \delta_{13}=0, H_{0}: \delta_{14}=0$ 
and $H_{0}: \delta_{15}=0$. In eq-13 the short run causality from real GDP, real capital, real interest rate and financial development index to labor force are examined respectively $H_{0}: \delta_{22}=0, H_{0}: \delta_{23}=0, H_{0}: \delta_{24}=0$ and $H_{0}: \delta_{25}=0$. In eq-14, short run causality from real GDP, labor force, real interest rate and financial development index to real capital are tested respectively $H_{0}: \delta_{32}=0, H_{0}: \delta_{33}=0, H_{0}: \delta_{34}=0$ and $H_{0}: \delta_{35}=0$. In eq-15 short run causality from real GDP, labor force, real capital and financial development index to real interest rate are tested respectively $H_{0}: \delta_{42}=0$, $H_{0}: \delta_{43}=0, H_{0}: \delta_{44}=0$ and $H_{0}: \delta_{45}=0$. In eq-16 short run causality from real GDP, labor force, real capital and real interest rate to financial development index are tested respectively $H_{0}: \delta_{52}=0, H_{0}: \delta_{53}=0, H_{0}: \delta_{54}=0$ and $H_{0}: \delta_{55}=0$. The long run causality is tested through the significance of error correction term (eqs. $12-$ 16). If the error correction term is negative and statistically significant, then we reject the null hypothesis of no long run causal relationship.

\section{Empirical results}

The results from the Augmented Dickey and Fuller (1979), and Ng (2001) and Perrson's unit root tests (2001) are reported in table 2. All the series are found to be I(1).

Table 2. Unit root tests results

\begin{tabular}{|c|c|c|c|c|}
\hline \multicolumn{5}{|c|}{ Augmented Dickey and Fuller unit root test } \\
\hline Variables & Level & & 1st Difference & \\
\hline $\operatorname{Ln}(L)$ & -0.974 & & $-4.11 * * *$ & \\
\hline $\operatorname{Ln}(K)$ & -0.846 & & $-3.111^{* *}$ & \\
\hline $\operatorname{Ln}(R I R)$ & -2.314 & & $-5.334 * * *$ & \\
\hline $\operatorname{Ln}(F D I)$ & -0.764 & & $-6.637 * * *$ & \\
\hline $\operatorname{Ln}(Y)$ & -1.226 & & $-3.614 * *$ & \\
\hline \multicolumn{5}{|c|}{$\mathrm{Ng}$ Perron unit root test } \\
\hline & $\mathrm{MZa}$ & $\mathrm{MZt}$ & MSB & MPT \\
\hline $\operatorname{Ln}(L)$ & -0.73 & -0.32 & 0.46 & 14.84 \\
\hline $\operatorname{Ln}(K)$ & -1.216 & -0.481 & 0.395 & 11.876 \\
\hline $\operatorname{Ln}(R I R)$ & -2.745 & -1.168 & 0.425 & 8.909 \\
\hline $\operatorname{Ln}(F D I)$ & 1.10927 & 0.90182 & 0.81299 & 49.1580 \\
\hline $\operatorname{Ln}(Y)$ & -1.618 & -0.562 & 0.347 & 10.061 \\
\hline \multicolumn{5}{|l|}{ 1st Difference } \\
\hline$\Delta \operatorname{Ln}(L)$ & $-6.69 *$ & -1.73 & 0.26 & 4.01 \\
\hline$\Delta \operatorname{Ln}(K)$ & $-10.399 * *$ & -2.221 & 0.213 & 2.582 \\
\hline$\Delta \operatorname{Ln}(R I R)$ & $-16.052 * * *$ & -2.832 & 0.176 & 1.527 \\
\hline$\Delta L n(F D I)$ & $-9.631 * *$ & -2.097 & 0.217 & 2.909 \\
\hline$\Delta \operatorname{Ln}(Y)$ & $-14.788 * * *$ & -2.709 & 0.183 & 1.692 \\
\hline
\end{tabular}

Notes: * $10 \%$;* $5 \%$; *** $1 \%$ : Level of significance. 
After determining the order of integration we explore existence of a long run relationship among the series. The optimal lag order is determined by applying the Schwartz Bayesian Criteria (SBC).

Table 3. Bound test for long run relationship

\begin{tabular}{|c|c|c|c|c|c|c|}
\hline \multicolumn{4}{|l|}{ Computed F-Statistic } & \multicolumn{3}{|c|}{7.861} \\
\hline \multirow[t]{4}{*}{ Level of Significance } & \multicolumn{6}{|c|}{ Critical Value Bounds } \\
\hline & \multicolumn{2}{|c|}{ Pesaran et al. (2001) } & \multicolumn{2}{|c|}{ Narayn (2005) } & \multicolumn{2}{|c|}{ Turner (2006) } \\
\hline & Lower & Upper & Lower & Upper & Lower & Upper \\
\hline & Bound & Bound & Bound & Bound & Bound & Bound \\
\hline $1 \%$ & 3.81 & 4.92 & 4.76 & 6.20 & 5.14 & 6.80 \\
\hline $5 \%$ & 3.05 & 3.97 & 3.28 & 4.63 & 3.80 & 4.78 \\
\hline $10 \%$ & 2.68 & 3.89 & 2.69 & 3.89 & 2.96 & 4.18 \\
\hline \multirow[t]{2}{*}{ Computed W-Statistic } & & & & & 47.162 & \\
\hline & \multicolumn{3}{|c|}{ Lower Bound } & \multicolumn{3}{|c|}{ Upper Bound } \\
\hline $1 \%$ & \multicolumn{3}{|c|}{12.13} & \multicolumn{3}{|c|}{17.87} \\
\hline $5 \%$ & \multicolumn{3}{|c|}{14.26} & \multicolumn{3}{|c|}{20.25} \\
\hline $10 \%$ & \multicolumn{3}{|c|}{12.13} & \multicolumn{3}{|c|}{25.62} \\
\hline
\end{tabular}

The computed F-statistic and $W$-Statistic presented in Table 3 are above the upper critical bound. This confirms cointegrating relation among the variables at the $1 \%$; level of significance. Having established a long run relationship among the variables, we now turn to the long run coefficients.

Estimated long run coefficients presented in Table 4 suggest that real interest rate (RIR) and FDI are negatively related to economic growth in Bangladesh. The results show that a 1 percent increase in RIR causes expected real economic growth to decline by $0.051 \%$, ceteris paribus. This result is consistent with the findings of Hye (2011) for India but not with those found by Khan and Qayyum (2007) for Pakistan, and Hye and Dolgopolova (2011) for China. Hye's (2011) estimates suggest that a 1\% increase in RIR lowers economic growth by $0.04 \%$ in India. Khan and Qayyum, and Hye and Dolgopolova found that a $1 \%$ increase in RIR enhances economic growth by $0.03 \%$ in Pakistan and $0.015 \%$ in China, on average ceteris paribus. Further a $1 \%$ increase in FDI impedes growth in real GDP by $0.254 \%$ in Bangladesh. This result is consistent with the earlier findings of Hye (2011) for India but not with those found by Ang (2007); Khan and Qayyum (2007); Kar et al. (2008), and Hye and Dolgopolova (2011) for Malaysia, Pakistan, Turkey, and China respectively, on average ceteris paribus. These authors found that a 1\% increase in FDI increases economic growth by $0.096,1.029$, 0.015 and $0.25 \%$, respectively. The negative coefficient found for FDI differs from some of the cross-country studies e.g., King and Levine (1993), Levine, Beck (2000) and Rioja and Valev (2004). The results of this study also do not agree with the earlier 
findings by Rahman $(2004,2007)$ on Bangladesh. Rahman found a positive effect of financial development on per capita income. The other factors - labour and capital - are positively associated to economic growth, as predicted by the standard growth theories.

Table 4. Long run coefficient

\begin{tabular}{ccc}
\hline & \multicolumn{2}{c}{ Dependent Variable: $\operatorname{Ln}(Y)$} \\
\cline { 2 - 3 } Regressor & \multicolumn{2}{c}{ ARDL Based Regression } \\
\cline { 2 - 3 } & Coefficient & T-Ratio (Prob.) \\
\hline $\operatorname{Ln}(L)$ & 0.679 & $2.306(0.028)$ \\
\hline $\operatorname{Ln}(K)$ & 0.634 & $-3.015(0.000)$ \\
\hline $\operatorname{Ln}(R I R)$ & -0.051 & $-1.678(0.103)$ \\
\hline $\operatorname{Ln}(F D I)$ & -0.254 & $-0.174(0.862)$ \\
\hline Constant & -0.685 &
\end{tabular}

Table 5. Short run error correction coefficients

\begin{tabular}{|c|c|c|}
\hline \multicolumn{3}{|c|}{ Dependent Variable: $\Delta \operatorname{Ln}(Y)$} \\
\hline Variable & Coefficient & t-Statistic [Prob.] \\
\hline $\operatorname{Ln}(Y(-1))$ & -0.361 & $-2.107(0.044)$ \\
\hline$\Delta \operatorname{Ln}(L)$ & 0.376 & $1.669(0.107)$ \\
\hline$\Delta \operatorname{Ln}(K)$ & 0.085 & $1.532(0.137)$ \\
\hline$\Delta \operatorname{Ln}(R I R)$ & -0.011 & $-3.983(0.000)$ \\
\hline$\Delta \operatorname{Ln}(F D I)$ & -0.063 & $-2.656(0.013)$ \\
\hline $\operatorname{ECM}(-1)$ & -0.078 & $-5.323(0.000)$ \\
\hline Constant & -0.011 & $-1.004(0.324)$ \\
\hline R-squared & \multicolumn{2}{|c|}{0.688} \\
\hline Adjusted R-squared & \multicolumn{2}{|c|}{0.616} \\
\hline F-statistic (Prob.) & \multicolumn{2}{|c|}{$9.572(0.000)$} \\
\hline Akaike info criterion & \multicolumn{2}{|c|}{-6.491} \\
\hline Schwarz criterion & \multicolumn{2}{|c|}{-6.173} \\
\hline Hannan-Quinn criter. & \multicolumn{2}{|c|}{-6.384} \\
\hline Durbin-Watson stat & \multicolumn{2}{|c|}{2.303} \\
\hline
\end{tabular}

The short run results reported in Table 5 indicate that the coefficient of RIR and FDI are negatively associated to economic growth. Economic growth responds positively to labor and capital and both are significant in the short run. The error correction term $\left(E C M_{t-1}\right.$ in table 5) is negative and statistically significant. This term indicates the speed of adjustment needed to restore equilibrium in the long run. A relatively high but negative ECM implies a faster adjustment process. For instance, the value of ECM 0.078, means the disequilibrium caused by of the previous year's shock is adjusted by average $7.8 \%$ to restore the long run equilibrium per year. 
Table 6. Conditional Granger causality test

\begin{tabular}{lcccccc}
\hline \multicolumn{5}{c}{ Short Run Causality } & Long run \\
\hline & $\operatorname{Ln}(Y)$ & $\operatorname{Ln}(L)$ & $\operatorname{Ln}(K)$ & $\operatorname{Ln}(R I R)$ & $\operatorname{Ln}(F D I)$ & Causality \\
\hline $\operatorname{Ln}(Y)$ & - & $2.381(0.100)$ & $1.219(0.316)$ & $4.958(0.017)$ & $9.751(0.001)$ & -4.721 \\
& & & & & & $(0.000)$ \\
\hline $\operatorname{Ln}(Y)$ & $1.178(0.328)$ & - & $0.113(0.893)$ & $1.431(0.262)$ & $0.131(0.878)$ & -0.395 \\
& & & & & & $(0.696)$ \\
\hline $\operatorname{Ln}(K)$ & $0.928(0.411)$ & $1.127(0.343)$ & - & $0.791(0.467)$ & $0.456(0.641)$ & -0.824 \\
& & & & & & $(0.419)$ \\
\hline $\operatorname{Ln}(R I R)$ & $2.041(0.156)$ & $2.421(0.114)$ & $0.195(0.823)$ & - & 4.1603 & -0.742 \\
& & & & & $(0.031)$ & $(0.466)$ \\
\hline $\operatorname{Ln}(F D I)$ & $1.354(0.281)$ & $2.439(0.112)$ & $3.211(0.061)$ & $0.986(0.391)$ & - & $0.661(0.515)$ \\
\hline
\end{tabular}

Table 6 shows the results of conditional Granger causality test. With respect to equation (12), labor force, real interest rate and financial development index causes real GDP in the short-run. The error correction term is statistically significant which suggests longrun causality. The equations $(13,14)$ show that none of the variables causes the labor force and gross capital formation in the short run. However, the error correction term is statistically insignificant which suggests that labor force and gross capital formation is not responsive to adjustments towards long-run equilibrium; i.e. no long run causality. The labor force and financial development index Granger cause the real interest rate in the short run, and the error correction term is insignificant. The result confirms no long run causality. Labor force and gross fixed capital formation Granger cause financial development index in the short run, and are positive. The insignificant error correction terms indicates no long run causality.

\section{Rolling regression analysis}

This study employs rolling window method to estimate and evaluate the stability of the model. Generally, we assume that the model parameters remain same over the sample period. However, as economic conditions change, so do the variables; which render such assumption untenable. Rolling window regression method allows us to examine parameter stability. Using the technique, we can estimate the coefficient of each observation of the sample size by setting the size of rolling window. If the economic variables fluctuate overtime, the technique can capture such instability.

Figures 2 through 6 present the results of the rolling regression. The solid line represents the estimated coefficient. The dotted lines show two standard deviation bands as an indicator of the significance of the coefficients.

Figure 2 shows graph of labor coefficients. The solid line in the graph shows annual long run coefficient which is greater than zero throughout sample period. Capital negatively affects the economic growth in the years of 1986-1990 and 2008 (Figure 3). Figures 4 and 5 portray the coefficients of RIR and FDI respectively. RIR is negative for the years 1986-1998, 2006 and 2007. The FDI is also negative for the years 1987 to 1988 , 1992 to 1999, 2002 to 2006, 2008 and 2009.Overall, the RIR and FDI are negatively linked to economic growth (see Table 4). The Figure 6 shows the graph of the intercept. 


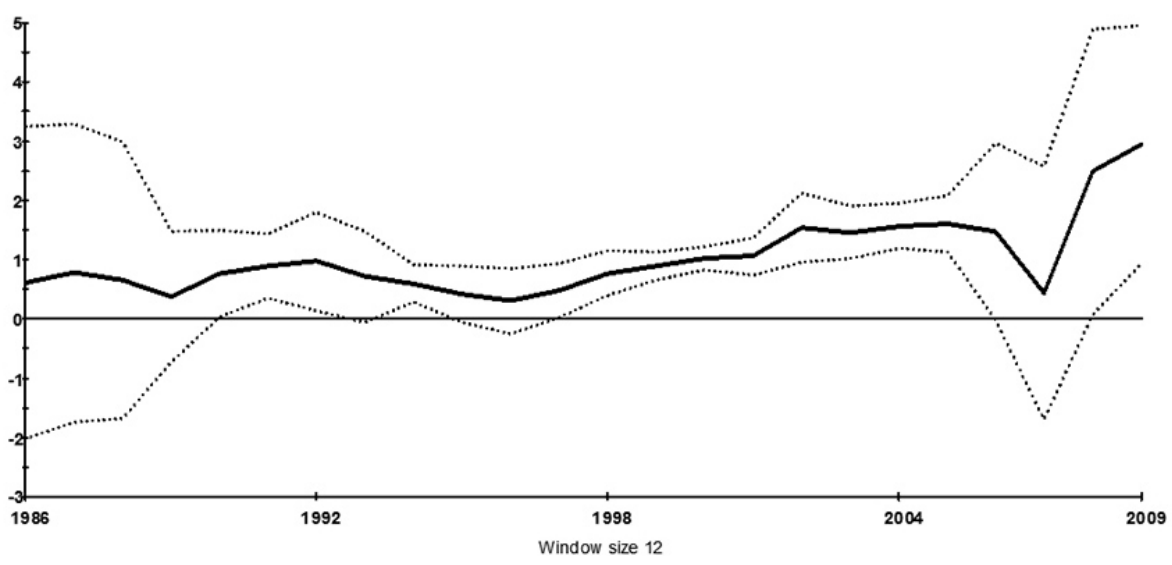

Fig. 2. Coefficient of $\operatorname{Ln}(\mathrm{L})$ and its two*S.E. bands based on rolling OLS

(Dependent Variable: Ln(Y); Total no. of Regressors: 5)

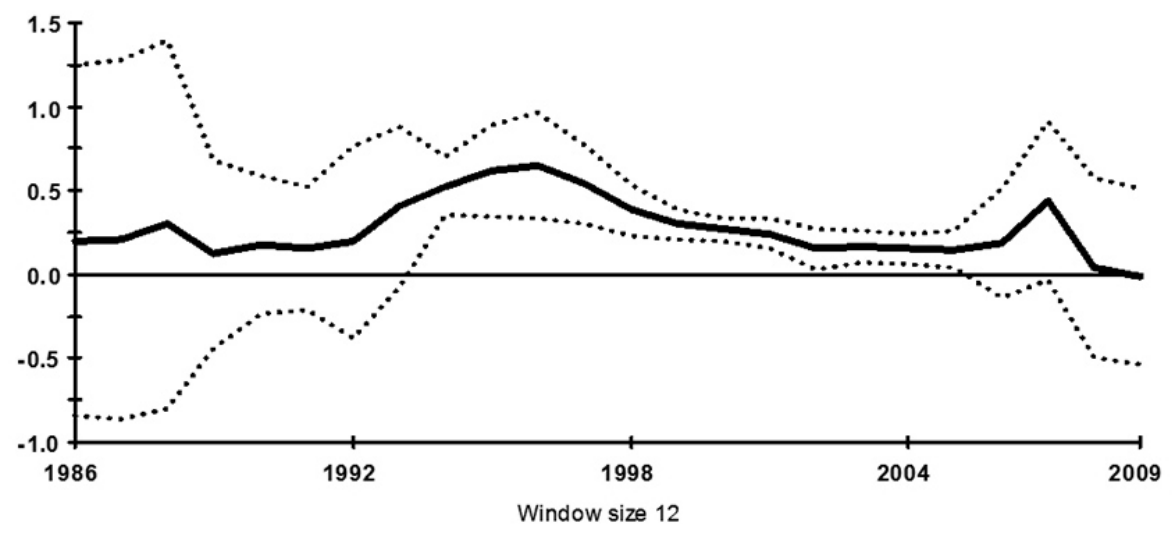

Fig. 3. Coefficient of $\operatorname{Ln}(\mathrm{K})$ and its two*S.E. bands based on rolling OLS (Dependent Variable: Ln(Y); Total no. of Regressors: 5)

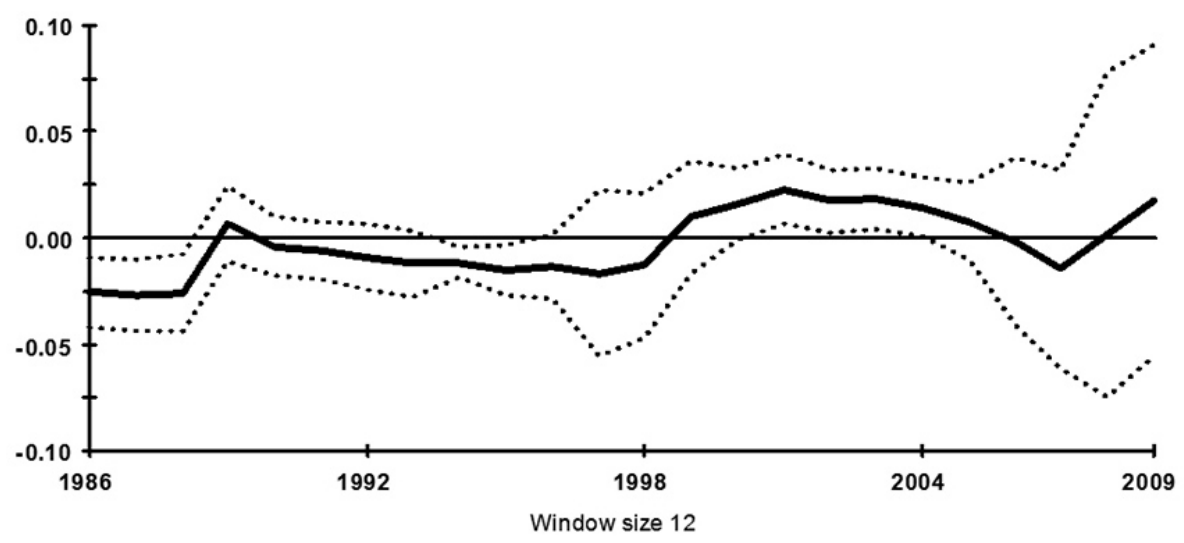

Fig. 4. Coefficient of $\operatorname{Ln}(\mathrm{RIR})$ and its two*S.E. bands based on rolling OLS

(Dependent Variable: Ln(Y); Total no. of Regressors: 5) 


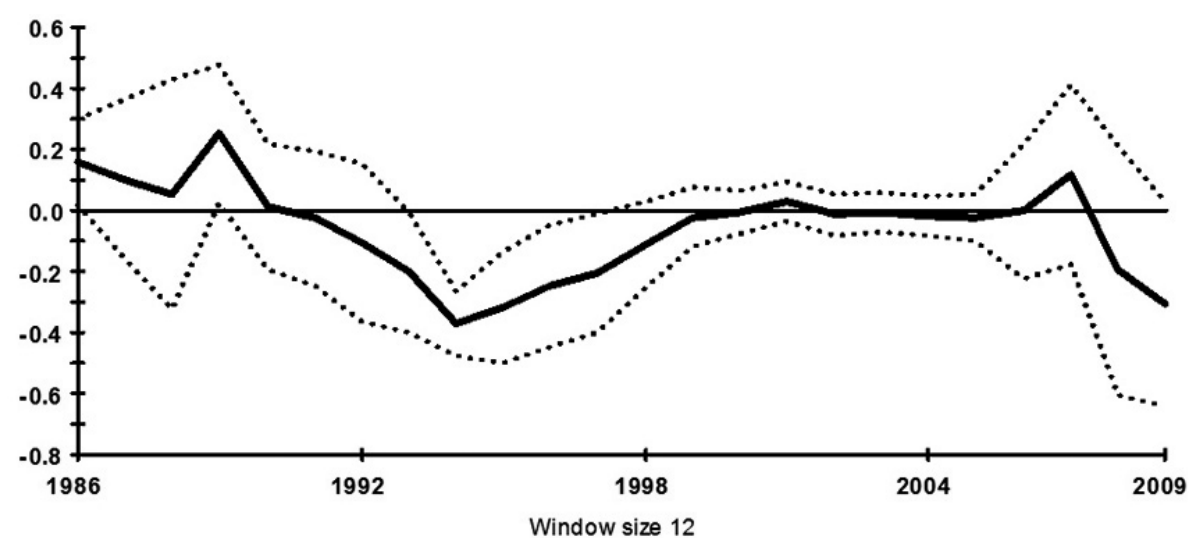

Fig. 5. Coefficient of $\operatorname{Ln}(\mathrm{FDI})$ and its two*S.E. bands based on rolling OLS

(Dependent Variable: $\operatorname{Ln}(\mathrm{Y})$; Total no. of Regressors: 5)

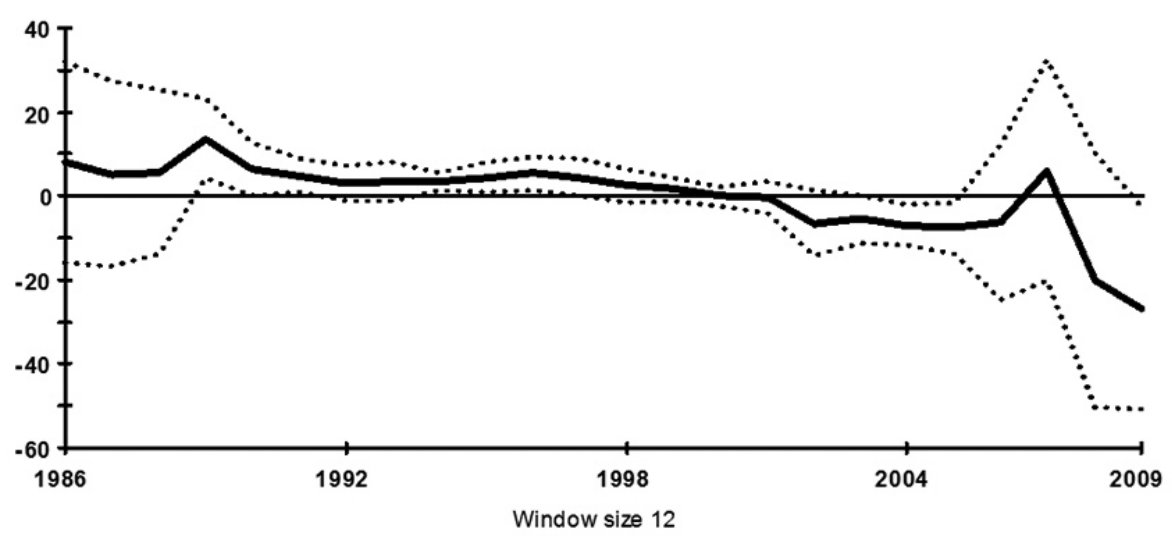

Fig. 6. Coefficient of INPT and its two*S.E. bands based on rolling OLS

(Dependent Variable: Ln(Y); Total no. of Regressors: 5)

\section{Conclusion}

In this paper we construct the first ever financial development index (FDI) for Bangladesh to examine the empirical relationship between FDI and economic growth. The Augmented Dickey Fuller and the Ng-Perron unit root tests to determine the order of integration, and the Autoregressive Distributed Lag (ARDL) approach to cointegration have been employed for a long run relation among the series. The rolling window regression approach is used to assess the stability of the parameters.

The results show that RIR and FDI are negatively related to economic growth both in the long and the short run. A 1\% increase in RIR and FDI lowers real economic growth by 0.051 and $0.254 \%$ respectively in the long run. While these findings lend support the theoretical justifications of Van Wijnbergen (1983), Taylor (1983), Lucas (1988), Mauro (1995) and Singh (1997) who anticipated that financial development would impede economic growth; studies of Wizarat and Hye (2010), and Hye (2011) find a negative 
relationship between economic growth and financial development in Pakistan and India. Some of the results did not lend support the theoretical model of Schumpeter (1911), Goldsmith (1969), Hicks (1969), and McKinnon (1973) and Shaw (1973). Ang (2007) found a $1 \%$ increase in FDI enhances economic growth by $0.096 \%$ in Malaysia. Khan and Qayyum (2007) found a1 percent increase in RIR and FDI enhances economic growth by 0.03 and $1.029 \%$ respectively in Pakistan; and Kar et al. (2008) found a 1\% increase in FDI promotes economic growth by $0.015 \%$ for Turkey. Hye (2011) found $1 \%$ increase in RIR and financial indicator enhances economic growth in China by 0.015 and $0.25 \%$, respectively (all interpretations are on an average and ceteris paribus). The present paper rejects the positive relationship between finance and economic growth in Bangladesh found earlier by Rahman (2004, 2007).

The other factors - labor and capital-used in study are positively associated to economic growth, as expected. The granger causality results indicate that labour force, real interest rate and financial development index Granger cause real economic growth in the short and the long run. Further the financial development index cause real interest rate in the short run only. More importantly, we could not find causality from financial indicators (Financial Development Index and real interest rate) to investment (Real gross fixed capital formation); and investment to economic growth as suggested by the McKinnon Shaw school of thought that financial reforms improve the efficiency of financial sector, thus enhances level of productive investment and ultimately a stable economic growth.

Further, we deepen the analytical rigor by estimating the coefficients of each observation using the rolling regression technique. The rolling window regression results show that the RIR is negative for the years 1986-1998, 2006 and 2007. The FDI is also negative for the years 1987 to 1988, 1992 to 1999, 2002 to 2006, 2008 and 2009.

Overall, the findings support the neo-structuralist position of Van Wijnbergen (1983), Taylor (1983), Lucas (1988), Mauro (1995) and Singh (1997) that financial liberalization impedes economic growth. Based on the findings of this study, the following policy implications emerge:

There is need to properly realign financial reforms to boost productive investment and thus economic growth in Bangladesh.

Policy makers should reduce loans to the non-performing agricultural and industrial sector. Such loans are higher in Bangladesh compared to other emerging economies (Bahar 2009).

It is vital to improve the risk management system. Experience of some developing countries like Argentina, Chile, Columbia, Brazil, Mexico and Uruguay indicate that financial liberalization without risk management can trigger financial distress (Lee 1991).

Policy makers need to ensure that the expansion in financial sector does not create excessive inflation.

It is important to allocate bank credit to small and medium enterprises. Experience of emerging economies like China shows that these enterprises contribute $90 \%$ to the GDP; and are also important for employment generation and poverty alleviation. 
Policy maker should pursue financial policies that attract foreign direct investments in the country.

The implementation of financial reforms in isolation is counterproductive. For the reforms to succeed, it is necessary to establish stable macroeconomic (fiscal and monetary policies) and political environment.

\section{References}

Agénor, P. R. 2003. Does globalization hurt the poor?: Unpublished Manuscript. The World Bank.

Agung, F.; Ford, J. 1998. Financial Development, Liberalization and Economic Development in Indonesia, 1966-1996: Cointegration and Causality, Discussion Paper No: 98-12. University of Birmingham, Department of Economics.

Ahmed, A. D. 2007. Potential impact of financial reforms on savings in Botswana: an empirical analysis using a VECM approach, The Journal of Developing Areas 41(1): 203-220.

http://dx.doi.org/10.1353/jda.2008.0011

Ang, J. B. 2008. Survey of recent development in the literature of finance and growth, Journal of Economic Surveys 22(3): 536-576.

http://dx.doi.org/10.1111/j.1467-6419.2007.00542.x

Ang, J. B.; Mckibbin, W. J. 2007. Financial liberalization, financial sector development and growth: evidence from Malaysia, Journal of Development Economics 84(1): 215-233. http://dx.doi.org/10.1016/j.jdeveco.2006.11.006

Arphasil, P. 2001. Financial Liberalization and Financial Crisis: The Case of Thailand, in Masayoshi Tsurumi (Ed.). Financial Big Bang in Asia. Aldershot: Ashgate Publishing Limited, 167-189.

Bahar, H. 2009. Financial Liberalization and Reforms in Bangladesh, in National Workshop. Organized by UNESCAP/UNDP/Royal Monetary Authority of Bhutan. Thimptu.

Bandiera, O.; Caprio, G.; Honohan, P.; Schiantarelli, F. 2000. Does financial reform raise or reduce saving? Review of Economics and Statistics 82(2): 239-263. http://dx.doi. org/10.1162/003465300558768

Barro, R. J. 1991. Economic growth in a cross section of countries, Quarterly Journal of Economics 106(2): 407-443. http://dx.doi.org/10.2307/2937943

Beck, T.; Levine, R. 2004. Stock markets, banks and growth: Panel evidence, Journal of Banking and Finance 28(3): 423-442. http://dx.doi.org/10.1016/S0378-4266(02)00408-9

Behrman, J.; Birdsall, N.; Pettersson, G. 2009. Schooling Inequality, Crises, and Financial Liberalization in Latin America, Center for Global Development Working Paper No. 165.

Bencivenga, V. R.; Smith, B. D. 1991. Financial intermediation and endogenous growth. Review of Economic Studies 58(2): 195-209. http://dx.doi.org/10.2307/2297964

Buffie, E. F. 1984. Financial repression, the new structuralists, and stabilization policy in semiindustrialized economies, Journal of Development Economics 14(3): 305-322.

http://dx.doi.org/10.1016/0304-3878(84)90061-0

Carlin, W.; Mayer, C. 2003. Finance, Investment and Growth. Available from Internet: www. elsevier.com/locate/econbase.

Choe, C.; Moosa, I. A. 1999. Financial system and economic growth: the Korean experience, World Development 27(6): 1069-1082. http://dx.doi.org/10.1016/S0305-750X(99)00042-X

De Gregorio, J.; Guidotti, P. E. 1995. Financial development and economic growth, World Development 23(3): 433-448. http://dx.doi.org/10.1016/0305-750X(94)00132-I 
Demirgucs-Kunt, A.; Enrica, D. 2001. Financial Liberalization and Financial Fragility, in G. Caprio, P. Honohan, J. E. Stiglitz (Eds.). Financial Liberalization: How Far, How Fast? Cambridge: Cambridge University Press. http://dx.doi.org/10.1017/CBO9780511625886.005

Demirgucs-Kunt, A.; Levine, R. 1996. Stock market development and financial intermediaries: Stylized facts, World Bank Economic Review 10(2): 291-322.

http://dx.doi.org/10.1093/wber/10.2.291

Engle, R. F.; Granger, C. W. J. 1987. Co-integration and error correction: representation, estimation, and testing, Econometrica 55(2): 251-276. http://dx.doi.org/10.2307/1913236

Fase, M. M. G.; Abma, R. C. N. 2003. Financial environment and economic growth in selected Asian countries, Journal of Asian Economics 14(1): 11-21.

http://dx.doi.org/10.1016/S1049-0078(02)00237-3

Gertler, M.; Rose, A. 1994. Finance, Public Policy and Growth, in G. Caprio, I. Atiyas, J. Hanson (Eds.). Financial Reforms: Theory and Experience. New York: Cambridge University Press, 13-14.

Goldsmith, R. W. 1969. Financial Structure and Development. New Haven: Yale University Press.

Gregory, A. W.; Hansen, B. E. 1996. Residual based tests for cointegration in models with regime shifts, Journal of Econometrics 70(1): 99-126.

Griffith-Jones, S.; Gottschalk, R.; Cirera, X. 2003. The OECD Experience with Capital Account Liberalization, in The Proceeding of United Nations Conference on Trade and Development. United Nations, 71-107.

Gupta, K. L. 1984. Finance and Economic Growth in Developing Countries. London: Croom Helm.

Güryay, E.; Şafakli, O. V.; Tüzel, B. 2007. Financial development and economic growth: evidence from northern Cyprus, International Research Journal of Finance and Economics 8: 57-62.

Hassan, A. F. M. K.; Islam, M. R. 2005. Temporal causality and dynamics of financial development, trade openness and economic growth in Vector Auto Regression (VAR) for Bangladesh, 1974-2003: Implication for poverty reduction, The Journal of Nepalese Business Studies 2(1): 1-12.

Hicks, J. 1969. A Theory of Economic Growth. Oxford: Clarendon Press.

Hotelling, H. 1933. Analysis of a complex of statistical variables into principal components, Journal of Educational Psychology 24(6): 417-44. http://dx.doi.org/10.1037/h0071325

Hye, Q. M. A.; Wizarat, S. 2011. Impact of financial liberalization on agricultural growth: a case study of Pakistan, China Agricultural Economic Review 3(2): 191-209.

Hye, Q. A. M. 2011. Financial development index and economic growth: empirical evidence from India, The Journal of Risk Finance 12(2): 98-111. http://dx.doi.org/10.1108/15265941111112820 Hye, Q. A. M.; Dolgopolova, I. 2011. Economics, finance and development in China: JohansenJuselius Co-integration Approach, Chinese Management Studies 5(3): 311-324.

http://dx.doi.org/10.1108/17506141111163381

Jappelli, T.; Pagano, M. 1994. Saving, growth and liquidity constraints, Quarterly Journal of Economics 109(1):83-109. http://dx.doi.org/10.2307/2118429

Johansen, S. 1991. Estimation and hypothesis testing of cointegration vectors in Gaussian Vector Autoregressive models, Econometric 59(6): 1551-1580. http://dx.doi.org/10.2307/2938278

Jung, W. S. 1986. Financial development and economic growth: International evidence, Economic Development and Cultural Change 34(2): 333-346. http://dx.doi.org/10.1086/451531

Kang, S. M.; Kim, M. S.; Lee, M. 2002. The trends of composite environmental indices in Korea, Journal of Environmental Management 64(2): 199-206. http://dx.doi.org/10.1006/ jema.2001.0529 
Kar, M.; Peker, O.; Kaplan, M. 2008. Trade liberalization financial development and economic growth in the long run: the case of Turkey, The South East European Journal of Economics and Business 3: 25-38.

Khan, M. A.; Qayyum, A. 2007. Trade Liberalization, Financial Sector Reforms and Growth. Available from Internet: http://mpra.ub.uni-muenchen.de/2655/1/MPRA_paper_2655.pdf.

Khan, S.; Islam, F. 2008. Was China the first domino? Revisiting the Asian currency crisis, Economics Letters 98(3): 275-281. http://dx.doi.org/10.1016/j.econlet.2007.05.009

Kelly, R.; Mavrotas. G. 2003. Financial sector development - futile or fruitful? An examination of the determinants of savings in Sri Lanka, WIDER Discussion Paper No. 14. United Nations University.

King, R. G.; Levine, R. 1993. Finance, Entrepreneurship and Growth: Theory and Evidence. World Bank MIMEO.

Laeven, L. 2003. Does financial liberalization reduce financial constraints?, Financial Management 32(1): 5-35. http://dx.doi.org/10.2307/3666202

La Porta, R.; Lopez-de-Silanes, F.; Shleifer, A. 2002. Government ownership of banks, Journal of Finance 57(1): 265-301. http://dx.doi.org/10.1111/1540-6261.00422

Lee, J. S. 1991. Financial sector and economic development: a survey, Economics and Development Resource Center Report No. 55 (September).

Levine, R. 1997. Financial development and economic growth: views and agenda, Journal of Economic Literature 35(2): 688-726.

Levine, R.; Zervos, S. 1998. Stock market, banks, and economic growth, American Economic Review 88(3): 537-558.

Levine, R.; Beck, T. 2000. Financial intermediation and growth: causality and causes, Journal of Monetary Economics 46(1): 31-77. http://dx.doi.org/10.1016/S0304-3932(00)00017-9

Lewis, W. A. 1955. The Theory of Economic Growth. London: George Allen and Unwin.

Lucas, R. E. Jr. 1988. On the mechanics of economic development, Journal of Monetary Economics 22(1): 3-42. http://dx.doi.org/10.1016/0304-3932(88)90168-7

Luintel, K. B.; Khan, M. 1999. A quantitative reassessment of the finance growth nexus: evidence from a multivariate VAR, Journal of Development Economics 60(2): 381-405.

http://dx.doi.org/10.1016/S0304-3878(99)00045-0

Lyons, S. E.; Murinde, V. 1994. Cointegration and Granger - causality testing of hypotheses on supply-leading and demand-following finance, Economic Notes 23(2): 308-316.

Mattoo, A.; Rathindran, R.; Subramanian, A. 2006. Measuring services trade liberalization and its impact on growth: an illustration, Journal of Economic Integration 21: 64-98.

Mauro, P. 1995. Stock markets and growth: a brief caveat on precautionary savings, Economics Letters 47(1): 111-116. http://dx.doi.org/10.1016/0165-1765(94)00511-Y

McKinnon, R. I. 1973. Money and Capital in Economic Development. Washington, DC: Brookings Institution.

Mete, F. 2007. Financial Liberalization and currency Crises: The Case of Turkey. Available from Internet: http://findarticles.com/p/articles/mi_qa5415/is_200704/ai_n21290633.

Mohammad, S. 2009. A Reassessment of finance-growth nexus for Pakistan: under the investigation of FMOLS and DOLS techniques, The IUP Journal of Applied Economics 1: 65-80.

Murinde, V.; Eng, F. S. H. 1994. Financial development and economic growth in Singapore: Demand-following or supply-leading?, Applied Financial Economics 4(6): 391-404.

http://dx.doi.org/10.1080/758518671

Nair, L. R. 2004. Financial Liberalization and Household Saving in India. Available from Internet: http://www.atlanticcommunity.org/index/Open_Think_Tank_Article/Financial_Sector_Liberalization_and_Household_Savings_in_India. 
Nair-Reichert, U.; Weinhold, D. 2001. Causality tests for cross-country panels: A new look at FDI and economic growth in developing countries, Oxford Bulletin of Economics and Statistics 63(2): 153-171. http://dx.doi.org/10.1111/1468-0084.00214

Narayan, P. K.; Smyth, R. 2004. The relationship between the real exchange rate and balance of payments: Empirical evidence for China from co-integration and causality testing, Applied Economic Letters 11(5): 287-291. http://dx.doi.org/10.1080/1350485042000221535

Narayan, P. K. 2005. The saving and investment nexus for China: evidence from cointegration tests, Applied Economics 37(17): 1979-1990. http://dx.doi.org/10.1080/00036840500278103

$\mathrm{Ng}$, S. P. 2001. Lag Length selection and the construction of unit root test with good size and power, Econometrica 69(6): 1519-1554. http://dx.doi.org/10.1111/1468-0262.00256

Odedokun, M. O. 1989. Causalities between financial aggregates and economic activities in Nigeria: The results from Granger's test, Savings and Development 23(1): 101-111.

Pearson, K. 1901. On lines and planes of closest fit to systems of points in space, Philosophical Magazine 2(6): 559-572.

Pesaran, M. H.; Bahram, P. 1997. Working with Microfit 4.0: Interactive Econometric Analysis. New York: Oxford University Press.

Pesaran, M. H.; Shin, Y.; Smith, R. J. 2001. Bound testing approaches to the analysis of level relationships, Journal of Applied Econometrics 16(3): 289-326. http://dx.doi.org/10.1002/jae.616

Rahman, M. H. 2004. Financial development economic growth nexus: A case study of Bangladesh, The Bangladesh Development Studies 30(3/4): 113-120.

Rahman, M. H. 2007. Financial development - economic growth nexus in Bangladesh, Working Paper Series: WP 0707. Policy Analysis Unit (PAU): Bangladesh Bank. Available from Internet: http://ssrn.com/abstract $=1310460$.

Rioja, F. K.; Valev, N. T. 2004. Finance and the sources of growth at various stages of economic development, Economic Inquiry 42(1): 127-140. http://dx.doi.org/10.1093/ei/cbh049

Robinson, J. 1952. The Generalization of the General Theory and Other Essays. London: The McMillan Press Ltd.

Romer, P. M. 1986. Increasing returns and long run growth, Journal of Political Economy 94(5): 1002-1037. http://dx.doi.org/10.1086/261420

Rousseau, P. L.; Wachtel, P. 1998. Financial intermediation and economic performance: Historical evidence from five industrialized countries, Journal of Money, Credit and Banking 30(3): 657-678. http://dx.doi.org/10.2307/2601123

Rousseau, P.; Wachtel, P. 2000. Financial intermediation and economic performance: Historical evidence from five industrialized countries, Journal of Banking and Finance 2000: 1933-1957. http://dx.doi.org/10.1016/S0378-4266(99)00123-5

Rousseau, P. L.; Wachtel, P. 2005. Economic growth and financial depth: Is the relationship extinct already?, UNU-WIDER Discussion Paper 2005/10

Sachsida, A. 2001. Causality Test between Financial Deepening and Growth. Available from Internet: http://papers.ssrn.com/13/papers.cfm?abstract_id=271813.

Schumpeter, J. A. 1911. The Theory of Economic Development: An Inquiry into Profits, Capital, Credit, Interest and the Business Cycle. Translated and Reprinted 1961. New York: Oxford University Press.

Schumpeter, J. A. 1934. The Theory of Economic Development. Cambridge, MA: Harvard University Press.

Seetanah, B. 2008. Financial development and economic growth in an ARDL approach, Applied Economics Letter 4(43): 43-50.

Shaw, E. S. 1973. Financial Deepening in Economic Development. New York: Oxford University Press. 
Shrestha, M. B.; Chowdhury, K. 2007. Testing financial liberalization hypothesis with ARDL model approach, Applied Financial Economics 17(18): 529-1540.

http://dx.doi.org/10.1080/09603100601007123

Singh, A. 1997. Financial liberalization, stock markets and economic development, Economic Journal 107(442): 771-782. http://dx.doi.org/10.1111/j.1468-0297.1997.tb00042.x

Singh, A.; Singh, A.; Weisse, B. 2003. Corporate governance, competition, the new international financial architecture and large corporations in emerging markets, in The Proceeding of United Nations Conference on Trade and Development. United Nations, 1-70.

Sufian, F.; Habibullah, M. S. 2009. Determinants of bank profitability in a developing economy: empirical evidence from Bangladesh, Journal of Business Economics and Management 10(3): 207-217. http://dx.doi.org/10.3846/1611-1699.2009.10.207-217

Stiglitz, J. 1994. Economic growth revisited, Industrial and Corporate Change 3(1): 65-110. http://dx.doi.org/10.1093/icc/3.1.65

Turner, P. 2006. Response surfaces for an F-test for cointegration, Applied Economics Letters 13(8): 479-482. http://dx.doi.org/10.1080/13504850500401726

Van Wijnbergen, S. 1982. Stagflationary effects of monetary stabilization policies, Journal of Development Economics 10(2): 133-169. http://dx.doi.org/10.1016/0304-3878(82)90014-1

Wachtel, P. 2003. How much do we really know about growth and finance?, Reserve Bank of Atlanta-Economic Review 1: 33-46.

Wizarat, S.; Hye, Q. M. A. 2010. Financial reforms and industrial sector growth: bound testing analysis for Pakistan, South East European Journal of Economics and Business 5(2): 75-81.

Wood, A. 1993. Financial development and economic hrowth in Barbados: Causal evidence, Savings and Development 17(4): 379-390.

Wyplosz, C. 2001. How risky is financial liberalization in the developing countries?, G-24 Discussion Paper No. 14. United Nations: New York and Geneva, September 2001.

Wyplosz, C. 2002. How risky is financial liberalization in the developing countries?, Comparative Economics 44: 1-26.

Xu, Z. 2000. Financial development, investment, and economic growth, Economic Enquiry 38(2): 331-344.

Yay, G.; Oktayer, A. 2009. Financial development and economic growth - A comparative analysis, Romanian Journal of Economic Forecasting 6(3): 56-74.

Qazi Muhammad Adnan HYE is Ph.D student at the Economics Department, Faculty of Economics and Administration, University of Malaya, Malaysia. He received his M. Phil in Economics from the Applied Economics Research Centre, University of Karachi and MA in Economics from Islamia University of Bhawalpur, Pakistan. He is editor of Asian Economic and Financial Review. He has fourty one publications in various national and international refereed journals.

Faridul ISLAM teaches at the Utah Valley University, UT in the Department of Economics and Finance. Farid earned his MS from the London School of Economics and the PhD from University of Illinois at Urbana. He also worked at the Wharton Econometric Forecast Associates, PA. He published in Economics Letters, Journal of Asian Economics, Journal of Economic Development, Economic Change and Restructuring, Journal of Developing Areas, The International Trade Journal, Bangladesh Development Studies among others. 